$\mathrm{I} \mathrm{N}$ this work the author gives a description of the various stages through which india-rubber passes from the time when it oozes out of the tree until it leaves the factory, a finished article, fashioned and fit for the service of man. The book is expressly designed for the general reader. It does not, except incidentally, deal with the chemistry of india-rubber, nor with the minute details of manufacture; the volume is neither a laboratory guide nor a factory handbook. There are, however, many people interested in india-rubber who are neither chemists nor manufacturers, and the author thinks that a volume conceived on broad general lines to expound the natural and commercial history of rubber cannot be deemed a superfluity. Similarly it may, perhaps, not be amiss to give here a short outline of the matter for the benefit of those readers of NaTURE who, likewise, are neither chemists nor manufacturers.

Many species of plants are now known to yield marketable rubber. They range from the lofty Hevea braziliensis of the Amazon swamps to the Landolphia

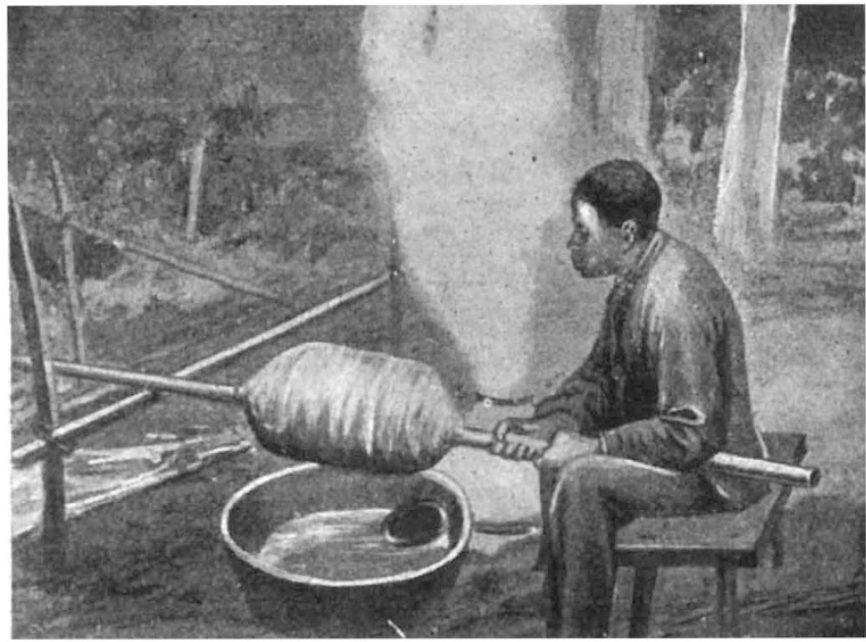

Smoking Para rubber with palm nuts by the method which has recently superseded the paddle to a great extent. From "India-Rubber and its Manufacture." article.

\section{THE PRODUCTION AND MANIPULATION OF INDIA-RUBBER.}

are also present resinous bodies, relatively small in amount, but important in their effect upon the quality of the rubber, that are not eliminated by washing. The cleaned rubber is " compounded" where necessary (i.e. having regard to the purpose it is destined to serve) by kneading it with various mineral in gredients, such as antimony sulphide, iron oxide, litharge, and barium sulphate, and is eventually vulcanised by treatment with sulphur before it emerges in its final form as motor-tyre, cable, or other

Mr. Terry writes on these subjects with the authority of personal knowledge, though perhaps without the lightness of touch desirable in a work of this character. Probably the second and fifth chapters of the book will be found of the most general interest. They treat respectively of "the production of raw rubber " and of "india-rubber plantations," giving as fully as the scope of the work allows a sketch of the present aspect of these matters.

Among points mentioned as calling for special attention, it is urged that more care should be given to the "tapping" operations, so that other juices in the trees shall not be allowed to mix with the rubber latex. Further, the exudations of other trees are sometimes mixed with the rubber latex for the purpose of increasing the bulk. The author mildly stigmatises this as an " injudicious " practice; it is surely a fraud. Another important point to which the attention of producers is directed is the desirability of removing or sterilising the fermentable albuminous substances present in the latex. They give rise to evil odours and become a nuisance, even if they do not injuriously affect the quality of the rubber itself-a point which is perhaps debatable.

As regards plantation rubber, an estimate of the area under cultivation about two years ago gave a total of some $\mathrm{I}_{5} \mathrm{o}$,ooo acres, and this, no doubt, has now considerably increased. The chief regions concerned are Ceylon (40,00o acres), the Malay Peninsula $(38,000)$, Africa (33,000), Mexico (10,000), and India (8000). Young plantations in a more or less experimental stage, covering in the aggregate some 20,000 acres, are also found in Borneo, Java, Brazil, Venezuela. Ecuador, Central America, and the West Indies. As to the quality of the plantation rubber, recent experiments seem to indicate that, judged by vulcanisation tests on a creepers of West Africa and the Clitandra shrubs, a foot or two high, the rhizomes of which yield the " rootrubber " of the Congo. The chief genera are Hevea, Manihot, and Micranda (Euphorbiaceæ); Castilloa and Ficus (Artocarpaceæ); Hancornia, Funtumia, and Landolphia (Apocynaceæ); and Callotropis (Ascle piadeæ). The bark of the trees yields a milky latex, which is obtained generally by " tapping," though sometimes by the wasteful process of felling the tree. In various ways the latex can be caused to coagulate, much as ordinary milk is made to "curdle"; and the separated coagulum, after undergoing a process of " curing," is the "raw " rubber of commerce. This raw rubber, which comes here in various formsloaves, biscuits, balls, cups, sheets, lumps, and slabs - contains water, sand, woody fibre, and other impurities, ranging in quantity from $I_{5}$ to $5^{\circ}$ per cent., which are removed by washing and rolling; and there

1 "India-Ruhber and its Manufacture; with Chanters on Gutta-Percha and Balata." By Hubert L. Terry. Pp. ix+294. (London: A. Constable and Co., Ltd., 1907.) Price $6 s$. net.

No. 1996 , vOL 77$]$ small scale, some plantation rubber at least is not inferior to the best " hard cure" Para. The author, however, remarks that up to the present there is a unanimous opinion amongst experts that plantation rubber is deficient in "strength" compared with the Brazilian forest product. Nevertheless, it commands a higher price, owing to its greater freedom from waste.

"Never before," say some recent writers, " have brokers or manufacturers had presented to them a raw rubber of the purity of the best plantation

For this very reason, they urge, it may well be that the present rough practical tests applied to the raw rubber are insufficient for proper valuation. At present the question of the relative merits is an open one; we shall probably know much more about it during the next year or two, when larger quantities the market.

C. Simmonds. rubbers." of the plantation product are expected to come into 